\title{
BALTIJOS ŠALIŲ ORO UOSTŲ EKONOMIKOS SEKTORIAUS PLE்TROS VERTINIMAS EKONOMIKOS GLOBALIZACIJOS SĄLYGOMIS
}

\author{
Eglè SIKORSKAITĖ-NARKUN*, Kęstutis PELECKIS \\ Ekonomikos inžinerijos katedra, Verslo vadybos fakultetas, \\ Vilniaus Gedimino technikos universitetas, Saulètekio al. 11, 10223 Vilnius, Lietuva \\ "El.paštas egle.sikorskaite@gmail.com
}

\begin{abstract}
Santrauka. Tyrimo reikšmė - oro uostų ekonomikos sektoriaus plètros vertinimas ekonomikos globalizacijos sąlygomis tampa vis svarbesnis kalbant apie bendrą šalies ekonomikos ir infrastruktūros sektoriaus plètrą ir jo vertinimą. Oro uostai ženkliai prisideda prie šalies BVP. Šiame darbe analizuojama Baltijos šalių ekonomikos sektoriaus plètra ekonomikos globalizacijos sąlygomis. Yra lyginami trys didžiausi tarptautiniai Baltijos šaliu oro uostai - Rygos, Vilniaus ir Talino. Tyrimo naujumas - globalizacijos sąlygomis, oro uostu ekonomikos sektoriaus problema yra prisitaikyti prie sparčiu pokyčių ir besikeičiančiu sąlygų, trūksta priemonių ịvertinti globalizacijos poveiki oro uostų ekonomikos sektoriaus plètrai. Straipsnio tikslas - nustatyti ekonomikos globalizacijos poveikị Baltijos šalių oro uostų ekonomikos sektoriaus plètrai. Aprašomi išoriniai veiksniai turintys ịtakos oro uostų ekonomikos sektoriaus plètrai. Nagrinėjami skirtingų autorių ir institucijų požiūriai $\mathfrak{i}$ ekonomikos sektoriaus plètrą globalizacijos sąlygomis. Tiriamas globalizacijos poveikis oro uostų ekonomikos sektoriaus plètrai. Tyrimui atlikti buvo apklausti ekspertai, apskaičiuotas Kendall konkordacijos koeficientas, svoriams nustatyti panaudotas AHP metodas, naudojami daugiakriteriniai metodai SAW ir TOPSIS. Pasirinkti vertinimo kriterijai: keleivių skaičius per metus, orlaivių judejjimo metiniai duomenys, krovinių gabenimas tūkst./t. per metus, oro vežejjų skaičius oro uoste, krypčių skaičius. Analizuojama bendradarbiavimo ir tinklo kūrimo būtinybè. Tyrimo rezultatai parodè, kad labiausiai ị ekonomikos globalizacijos pokyčius reaguoja Rygos oro uostas, kitas Vilniaus oro uostas ir trečioje vietoje Estijos tarptautinis oro uostas.
\end{abstract}

Reikšminiai žodžiai: globali ekonomika, oro uostų ekonomikos sektoriaus plètra, globalizacija, Baltijos šalių oro uostai, inovacijos, technologijų plètra, infrastruktūros plètra.

\section{Ivadas}

Tyrimo aktualumas. Oro uostu plètra ekonomikos globalizacijos sąlygomis yra svarbi kalbant apie technologini pažangumą, modernizaciją oro transporto srityje, kuri neatsiejama nuo inovacinių procesų ir ekonominio augimo valstybėse. Pati globalizacija suponuoja daugybę galimybių inovacijų atsiradimui oro uostose ir aviacijoje, kurios apjungia daugybę skirtingų paslaugų ir funkcijų. Ekonomikos globalizacijos procesams, yra būdingas cikliškumas, tai suponuoja poreikị ịvairių ekonominių sektorių plètrą. Formuojasi identiška paklausa, tam reikalinga identiška pasiūla ir su lyg kiekvienu ciklu apimanti vis didesnę rinką viso pasaulio mastu. Užtikrinant aukštos kokybès paslaugų ir produktų pasiūlą, kuri sugebètų aptarnauti stipriai didèjančius srautus, Baltijos šalių oro uostams būtina ekonominè plètra, kuri sugebėtų efektyviai prisitaikyti prie dabartinès globalizacijos sąlygų, šiai dienai trūksta kompleksinių priemonių vertinimui atlikti ir ši ekonomikos dalis nėra pakankamai analizuojama.

Darbo problema. Siekiant plètoti Baltijos šalių oro uostų ekonomikos sektoriaus veiklą, trūksta priemonių, kurios padètų efektyviai įvertinti ekonomikos globalizacijos poveikị.

Tyrimo objektas. Baltijos šalių oro uostų ekonomikos sektoriaus plètra ekonomikos globalizacijos sąlygomis.

Darbo tikslas. Nustatyti ekonomikos globalizacijos poveikị Baltijos šalių oro uostų ekonomikos sektoriaus plètrai.

Tyrimo metodai. Mokslinès literatūros analizè ir sintezè. Antrinių duomenų apžvalga. Ekspertinis vertinimas. Daugiakriterinis vertinimas.

Oro transportas yra viena iš sparčiausiai augančiu pramonės šakų. Kalbant apie oro uostų poveikị šalies ekonomikai negalime apsiriboti vien tiesioginiu buhalteriniu vertinimu, oro uostas yra plati infrastruktūros dalis. Technologijų ir inovacijų amžiuje svarbu greitai ir orientuotai prisitaikyti prie ekonomikos globalizacijai būdingu pokyčiu ịvairiose srityse. Dabartinei rinkai būdinga stagnacijos problema, verslo etikos nebuvimas. Norint gebėti konkuruoti globaliu mastu svarbu kritinis požiūris, kuris turi būti orientuotas ị sinergijos paiešką. Svarbus pačiu 
valstybių indèlis ị oro uostų ekonominę plètrą, nes oro uostai iki šios dienos stipriai prisideda prie BVP kūrimo. Straipsnyje nagrinejjamas Baltijos šalių oro uostų ekonomikos augimo poveikis bendrai tos valstybės ekonomikai. Nagrinejamas dabartinis ekonomikos augimą skatinantis priemonių kompleksas ir jo efektyvumas ekonomikos globalizacijos sąlygomis. Analizuojama, kaip valstybės išnaudoja savo geografinę padètį siekiant efektyvesnių plètros galimybių.

Taigi, oro transporto plètra yra neatsiejama nuo valstybès ekonomikos plètros ir augimo, ekonomikos nuosmukiai ir paklilimai tiesiogiai veikia oro uostų veiklą. Taip pat oro uostas yra priklausomas nuo valstybių ekonominio bendradarbiavimo ir plètros.

\section{Baltijos šalių oro uostų ekonomikos sektoriaus plètra}

Baltijos šalių oro uostų ekonomikos sektoriaus plètra yra svarbi viso regiono mastu. Geografinè padètis ịpareigoja ir suponuoja išnaudoti tranzitui suteiktas galimybes Baltijos šalyse ir tam būtina atitinkama plètra apimanti didelę infrastruktūros dalị. Oro uosto infrastruktūros plètra, kuri užtikrintų kuo efektyvesnị oro uosto veikimą yra ne tik oro uosto, kaip subjekto plètra, tačiau apima labai plačią visos valstybės infrastruktūros plètros dalị. Reikalingas ir pačios valstybès didelis indèlis ị oro uostų plètrą. Tai labai aukštą paslaugų kokybę ir saugumo lygi užtikrinantys subjektai, kuriuos kontroliuoja įvairios tarptautinès organizacijos iš jų pagrindinès yra Jungtinių tautų organizacijos specializuota (JTO) bei Tarptautinè civilinès aviacijos organizacija (TACO). Oro uostas svarbus savo gebèjimu vykdyti modalinius perkèlimus tarp sausumos ir vandens, užtikrinantis greičiausią keliavimą ir siuntų gabenimą. Globalizacijos sąlygomis svarbus verslo sektoriuje, tarptautinejje politikoje, saugumo užtikrinimui, gynybos sektoriuje. Apimant vis didesnę visos infrastruktūros dali globaliu mastu, didžiausias dèmesys skiriamas aviacijos saugumo užtikrinimui. Taip oro uostai, su visais savo resursais, daro reikšmingą įtaką globaliai ekonomikai. Reikalingas efektyvus balansavimas tarp viešųų interesų, valdytojų ir oro uostų operatorių (Baltazar et al., 2018).

Yra daug skirtingų požiūrių, kurie apibrèžia oro uostų ekonomikos sektoriaus plètrą ekonomikos globalizacijos sąlygomis. Vienas iš požiūrių - inovacijos, oro rinkos liberalizavimas išsivysčiusiose ekonomikose, pigių skrydžių svarba, didèjančios pajamos besivystančiose šalyse skatina oro uostų ekonomikos sektoriaus augimą globaliu mastu (Sentance, 2015). Aviacijos sukurtas pasaulinis verslo ir keliautojų tinklas apima visą pasaulį, kiekvieną kraštą. Tai yra saugiausia ir greičiausia transporto priemone, skatinanti tvarų ekonomikos augimą. Stiprus ir prieinamas oro transporto tinklas plečia vietos galimybes įsigyti užsienio rinkos prekių, suteikia kultūrinių galimybių, skatina socialinius mainus, sustiprina humanitarinę pagalbą ekstremaliomis sąlygomis ir krizių metu (The International Air Transport Association [IATA], 2017). Visa infrastruktūra turi būti patogiai suderinta su oro uostų plètra įskaitant atvykimą, išvykimą ir apsistojimą taip užtikrinant plètros efektyvumą. Atvykimas ị oro uostą turi būti patogus, siekiant išvengti spūsčių (Airport Aviation Association, 2016).

Apibendrinant galime sakyti, kad oro uostų plètra skatina ekonomikos augimą globaliu mastu ir priešingai, ekonomikos globalizacija ir ekonomikos augimas skatina oro uostų plètrą, inovacijų atsiradimą. Oro uostas tiesiogiai priklauso nuo visos infrastruktūros plètros, kuri bent kažkiek yra susijusi su oro uostu. Oro uostų infrastruktūra sparčiai plečiasi, užtikrindama aukštus saugumo ir kokybės standartus, kuriuos griežtai kontroliuoja ivairios tarptautinès organizacijos.

Nuosekli ir suderinta pasaulinè tarptautinio oro transporto reguliavimo sistema, padès pašalinti kliūtis ekonominiam tvarumui ir maksimaliai padidins aviacijos indèlị i ekonominę plètrą. Nagrinèti autoriai savo darbuose įrodè, kad oro uostų veiklos efektyvumui didelę įtaką daro makroekonominiai pokyčiai. Savo tyrimuose nustatè, kad kintantys makroekonomiai rodikliai daro ịtaką keleivių skaičiui oro uostuose ir bendram aviacijos užimtumui (Chaouk et al., 2020). Siekiama efektyvaus išteklių naudojimo ir valstybių bendradarbiavimo, tikslių duomenų pateikimo ir priemoniu prieinamumo. Reikalingos prognozès užtikrinančios aviacijos plètros aspektams įvertinti (ICAO, 2018). Aviacija suponuoja globalios ekonomikos teigiamus pokyčius besivystančiose šalyse, tačiau pasauliniu mastu vykstantys ịvykiai, kurie nekelia pasitikejjimo, lëtina augimą išsivysčiusiose šalyse. Oro transportas yra viena sparčiausiai besivystančių ekonomikos šakų, darančių įtaką šalių ekonominei, politinei ir socialinei raidai globaliu mastu.

Oro uostu ir aviacijos veikla yra reikšminga viso pasaulio ekonomikai ir prisideda prie kiekvienos šalies ekonomikos pokyčių. Taip pat valstybių institucinė sistema daro įtaką oro uostų veiklai. Prastai išvystyta valstybės institucinè sistema daro neigiamą poveiki valstybių oro uostams. Oro uostas veikia tokioje aplinkoje, kur veikia tvirti instituciniai susitarimai ir yra tvirta teisine bazé, o tai padeda oro uosto valdytojams pasiekti didesni efektyvumo lygi (Chaouk et al., 2020). Šiame straipsnyje nagrinėsime Baltijos šalių oro uostu ekonomikos sektoriaus plètrą, kuri betarpiškai susijusi su šių šalių ekonomikos augimu. Pasirinktų šalių geografinė padètis panaši, tai leis objektyviai įvertinti šių šalių oro uostų plètros galimybes. Globalizacijos sąlygomis svarbu, kad kiekviena plètra būtų tvari ir atsižvelgtų i taršos ir triukšmo problemas, tai ne tik ūkio subjekto plètros klausimas, tai visos suinteresuotos visuomenès reikalas. Tvari plètra yra pažangi plètra.

Oro uostų ekonomikos sektoriaus pletra ekonomikos globalizacijos sąlygomis, tai cikliškumu pasižyminti, tvari, technologijomis grịsta ir pačios globalizacijos skatinama plètra, kuri betarpiškai įtakoja bendrą tos šalies ekonomikos augimą ir apima didžiają infrastruktūros dalį. 


\subsection{Rygos oro uosto ekonominès plètros ypatumai}

Rygos oro uostas (RIX) yra didžiausias tarptautinis oro uostas Baltijos šalyse. Siekiant užtikrinti efektyvią ekonominę plètrą RIX investuoja ị infrastruktūrą, atsižvelgdamas ị šiuolaikinių inovacijų poreikị ir keleivių srautu didèjimą. 2016-2019 m. plètros planas: antrojo greitèjimo riedejimo tako statyba, techninių tarnybų pastato rekonstrukcija, lietaus nuoteku kanalizacijos įrengimas oro uosto teritorijoje, ašies lempučiu montavimas lèktuvų stovèjimo aikštelèse, anglies dioksido išmetimo ị aplinką sumažinimas, aviacijos saugumo gerinimas. Planuojamos išlaidos plètrai - 13,5 mln.eur. (Ryga International Airport [RIX], 2015). Rygos oro uostas 2016-2036 m. planuoja investuoti $416 \mathrm{mln}$. eur. (žr. 1 lentelę).

1 lentelè. RIX investicijos ị plètrą (Lentelè sudaryta autorès pagal RIX, 2015)

\begin{tabular}{|c|c|c|c|c|}
\hline & $2016-2020 \mathrm{~m}$. & $2021-2025 \mathrm{~m}$. & $2026-2031 \mathrm{~m}$. & $2031-2036 \mathrm{~m}$. \\
\hline Infrastruktūra & 60 & 90 & 98 & 107 \\
\hline Saugumas & 14 & 16 & 6 & 12 \\
\hline IT & 6 & 1 & 4 & 2 \\
\hline
\end{tabular}

Akivaizdu, kad didžiausios investicijos bus skiriamos infrastruktūros plètrai norint neatsilikti nuo sąlygų, kurias diktuoja ekonomikos globalizacija. Remiantis neseniai paskelbtu tyrimu, kuri užsakẻ Tarptautine oro transporto asociacija IATA, aviacijos pramonè vaidina svarbų vaidmeni Latvijos prekyboje ir ekonomikoje. Remiantis „Oxford Economics“ atliktu tyrimu, aviacija sudaro 2,0 proc. Latvijos BVP, o pramoné palaiko darbo vietas 2,0 proc. šalies darbo jègos (Tallat-Kelpšaitè, 2019).

Rygos oro uostas konkuruoja netik tarp Baltijos šalių, bet lyginasi ir su Skandinavijos šalių oro uostu ekonomine plètra, tam labai dèkinga Rygos geografinè padètis, dèl to itin didelis dèmesys skiriamas tranzitui (žr. 2 lentelę).

2 lentelè. Pervežimo ir tiesioginio tranzito keleiviai (Lentelè sudaryta autorès remiantis RIX, 2019)

\begin{tabular}{|c|c|c|c|c|}
\hline Metai & $2016 \mathrm{~m}$. & $2017 \mathrm{~m}$. & $2018 \mathrm{~m}$. & $2019 \mathrm{~m}$. (sausis-rugpjūtis) \\
\hline Keleivių skaičius & 1472871 & 1786820 & 1984384 & 1629855 \\
\hline
\end{tabular}

Tiesioginio tranzito keleiviai ir pervežimai šiuolaikinės globalizacijos sąlygomis, kada oro transportas tampa vienu pagrindiniu ir patogiausiu, dèl savo greičio ir kainos santykio susisiekimo transportu sudaro dideles galimybes oro uosto plètrai, užsienio investicijoms, tai skatina bendra valstybès ekonomikos augimą. Rygos oro uostas yra pagrindinis Vilniaus oro uosto konkurentas.

\subsection{Talino oro uosto ekonominès plètros ypatumai}

Talino tarptautinis oro uostas yra didžiausias Estijos oro uostas. Siekiant pagerinti oro uosto infrastruktūros pajègumus, $2016 \mathrm{~m}$. buvo inicijuotas oro uosto eismo zonos ir keleiviu terminalo išplètimo ir modernizavimo projektas. I pletros projektą investuojama $127 \mathrm{mln}$. eur 2016-2020 m. Projektą remia Europos investicijų bankas (EIB) ir Šiaurès investicijų bankas (NIB) teikdami finansinę paramą, paskelbtą $2016 \mathrm{~m}$. gruodžio mèn. Per pastaruosius dešimt metų Talino oro uoste aptarnaujamų keleivių skaičius išaugo dvigubai, palyginti su prieš dešimt metų. Per tą patị laiką skrydžių iš Estijos kelionių vietų skaičius išaugo $40 \%$. Nuo šių metų oro uostas pradès planuoti savo keleivių terminalo plètrą, kad padidètu jo pajègumas aptarnauti 5-6 milijonus keleivių per metus(Vahtla, 2019). Talino oro uoste yra 16 vežėjų, iš jų, naujausias reguliarių skrydžių teikèjas yra „Wizzair“, kuris pradejo skristi iš Talino ị Kijevą ir Londoną $2018 \mathrm{~m}$. Nors šiemet ị Talino oro uostą atneše naujų krypčių, 2019 m. siekiama padidinti esamų maršrutų dažnị verslo keliautojams labiau tinkančiomis linijomis (Tallinn Airport, 2019). 2018 m. vasarą Talino oro uostas buvo nominuotas geriausiu Europos oro uostu, o 2019 metais antroje vietoje. Talino oro uostu sunku konkuruoti savo pajegumu, todèl siekiama tapti jaukiausiu oro uostu pasaulyje. Talino oro uostui praèję 2018 metai buvo nepaprastai sėkmingi: pajamos padidejo iki 43,8 mln. euru $(9 \%)$ ir EBITDA sudare $15,1 \mathrm{mln}$. eur $(8 \%)$, palyginti su metais prieš tai. Bendrovès grynasis pelnas padidejo beveik $16 \%$, palyginti su ankstesniais metais, ir sudare 7,5 mln. eurų (Tallinn Airport, 2019). Talino oro uosto ekonominis augimas sparčiai auga, prisitaikydamas prie augančios rinkos (žr. 3 lentelę).

3 lentelè. Talino oro uosto ekonominių rodiklių augimas lyginant 2017-2018 m. (Lentelè sudaryta autorés remiantis Tallinn Airport, 2019)

\begin{tabular}{|c|c|c|c|c|}
\hline Metai & Bendras turtas & Grynasis pelnas & Keleiviai & Investicijos \\
\hline 2017 & $181,4 \mathrm{mln} . / \mathrm{eur}$ & $6,5 \mathrm{mln} . / \mathrm{eur}$ & 2648361 & $22,7 \mathrm{mln} . / \mathrm{eur}$ \\
\hline 2018 & $189,7 \mathrm{mln} . / \mathrm{eur}$ & $7,5 \mathrm{mln} . / \mathrm{eur}$ & 3007644 & $32,8 \mathrm{mln} . / \mathrm{eur}$ \\
\hline
\end{tabular}


Iš lentelëje pateiktų duomenų matome, kad didejjant pelnui, keleivių srautui, bendram turtui tačiau investicijos sumažèjo. Tai paryškina stagnacijos problema rinkoje. Plètra turètų būti adekvati keleivių srautams ir pajamoms.

\subsection{Vilniaus oro uosto ekonominės plėtros ypatumai}

Vilniaus oro uostas (VNO) yra pagrindinis šalies tarptautinis oro uostas, konkuruojantis su Baltijos šalių didžiausiais tarptautiniais oro uostais. VNO aptarnauja 15 vežèjų iš jų daugiausiai perveža Wizzair ir Rynair. Iš VNO skrenda 63-kryptimis iš jų pagrindinès London Luton ir Varšuva (Lietuvos oro uostai, 2019). Vilniaus oro uoste, kaip ir visame pasaulyje, dèl ekonomikos globalizacijos įtakos, pastebimas ženklus ekonominis augimas, skatinantis ekonomikos sektoriaus plètrą (žr. 4 lentelę).

4 lentelè. Vilniaus oro uosto ekonominio sektoriaus augimas 2017-2018 m. (Lentelè sudaryta autorès remiantis VỊ Lietuvos oro uostai, 2019)

\begin{tabular}{|c|c|c|c|c|}
\hline Metai & Keleivių skaičius & Krovinių skaičius & $\begin{array}{c}\text { Neaviacinès veiklos } \\
\text { pajamos }\end{array}$ & Skrydžių skaičius \\
\hline $2017 \mathrm{~m}$. & $3,76 \mathrm{mln}$. & 9,58 tūkst./t & $11 \mathrm{mln} . / \mathrm{eur}$ & 39209 \\
\hline $2018 \mathrm{~m}$. & $4,9 \mathrm{mln}$. & 12,77 tūkst./t & $14,5 \mathrm{mln} . / \mathrm{eur}$ & 47197 \\
\hline
\end{tabular}

Būdama didžiausia civilinės aviacijos infrastruktūros paslaugų teikèja Lietuvoje, LOU yra vienas iš Lietuvos ekonomikos vystymosi katalizatorių, pritraukiančių tiesiogines užsienio ar vietinio verslo investicijas ir kuriančių darbo vietas. Taikydami įvairias skatinimo programas avialinijoms, oro uostai pritraukia papildomus skrydžius bei padidina keleivių srautus. Pastaraisiais metais matoma tendencija - Vilnius kasmet nuosaikiai didina krypčių skaičių ir artejja prie regiono lyderio pozicijos (Lietuvos oro uostai, 2019).

Tačiau šiuo metu VNO turima infrastruktūra dar nepritaikyta dabartiniam keleivių srautui ir netenkina minimalių keleivių patirties rodiklių, kurie yra kritiniai siekiant išplèsti Lietuvos pasiekiamumo žemèlapi pritraukiant naujas aviakompanijas bei naujas kryptis ir išlaikyti keleivių prieaugio galimybes. 2018 m. pradèta VNO rekonstrukcijos programa bus tęsiama iki 2022 metų. Šios programos metu bus į šiaurinę pusę išplèstas keleivių terminalas, praplèstas šiaurinis peronas ir sutvarkytos transporto prieigos, taip pat pastatytas naujas labai svarbių asmenų (angl. VIP) terminalas. Per 4 metus į VNO plètrą, rekonstrukciją, senos ịrangos ir technikos atnaujinimą iš viso bus investuota apie $130 \mathrm{mln}$. eurų. Sukurta infrastruktūra leis aptarnauti 2400 keleivių per valandą piko metu ir 7,5 mln. keleivių per metus. Pasiekti pajègumai leis aptarnauti keleivių srautus artimiausius 710 metų (Vİ Lietuvos oro uostai, 2019).

VNO ekonominio sektoriaus plètra neišvengiama, tačiau reikalingas tos plètros efektyvumo vertinimas siekiant prisitaikyti prie globalios ekonomikos sąlygų. Oro uosto plètra tai nėra tik kaip pačio subjekto plètra tai paliečia ir didelę dalị visuomenès, kuri yra tiesiogiai veikiama oro uosto veiklos. Taigi jeigu vienai visuomenės daliai oro uosto veikla yra naudinga, tai nereiškia, kad ir kitai visuomenès daliai tai nenaudinga dèl tokių kylančių problemų kaip: triukšmas, tarša. Vertinant oro uosto plètros efektyvumą, būtinas efektyvus su visuomene derybų vertinimas, kuris parodytų kuo mažesnę plètros žalą suinteresuotai visuomenès daliai.

\section{Metodika}

Siekiant ịvertinti Baltijos šalių oro uostų ekonominę plètrą ekonomikos globalizacijos sąlygomis buvo atliktas empirinis tyrimas, naudojant du daugiakriterinius metodus - SAW ir TOPSIS. Vertinant oro uostų ekonominę plètrą buvo pasirinkti šie vertinimo kriterijai: keleivių skaičius, orlaivių judejjimas, kroviniai tūkst/t., oro vežèjų skaičius oro uoste, tiesioginių krypčių skaičius (2018 m. duomenys). Buvo apklausti ekspertai kriterijų svarbumui nustatyti, ekspertų vertinimo suderinamumui nustatyti apskaičiuotas Kendall konkordacijos koeficientas, AHP metodu, remiantis ekspertų vertinimais, nustatyti kriterijų svoriai.

\subsection{Kendall konkordacijos koeficientas (W)}

Apskaičiuoti ekspertų vertinimo suderinamumą naudojamas Kendall konkordacijos koeficiento metodas (W). Rangų sumų vidurkis $a$ apskaičiuojamas pagal formulę:

$$
a=0,5 m(k+1),
$$

čia: $m$ - ekspertų skaičius; $k$ - ekspertizès objektų skaičius. 
Toliau apskaičiuojama nuokrypio nuo rangų vidurkio suma pagal formulę:

$$
S^{2}=\sum_{j=1}^{k}\left(\sum_{j=1}^{m} x_{i j}-a\right)^{2},
$$

čia $S^{2}$ kvadratų nuokrypio suma.

Toliau apskaičiuojama maksimali galima nuokrypio nuo rangų vidurkio suma pagal formulę:

$$
S_{\max }^{2}=\frac{m^{2}\left(k^{3}-k\right)-m \sum_{i=1}^{r} T_{l}}{12} .
$$

Konkordacijos koeficientas apskaičiuojamas pagal formulę:

$$
W=\frac{12 S^{2}}{m^{2}\left(k^{3}-k\right)-m T} .
$$

Suformuluojamos ir tiriamos šios hipotezès: $H_{0}$ - ekspertų vertinimai prieštaringi $(W=0) ; H_{a}$ : Ekspertų vertinimai panašūs $(W>0)$.

$$
\chi^{2}=W m(k-1)
$$

\subsection{AHP metodas}

AHP (angl. Analitic Hierarchy Process) metodu nustatome kriterijų svorius.

Pirmu žingsniu sudarome porinių palyginimų matricą:

Čia: $n-\mathrm{C}$ matricos rodiklių eilè; $C$ - rodiklių reikšmingumo santykiai:

$$
\left[\begin{array}{ccc}
C_{11} & \cdots & C_{1 n} \\
\vdots & \ddots & \vdots \\
C_{n 1} & \cdots & C_{n n}
\end{array}\right]
$$

Toliau sudarome normalizuotų porinių palyginimų matricą:

$$
X_{i j} \quad=\frac{C_{i j}}{\sum_{i, j=1}^{n} C_{i j}}=\left[\begin{array}{ccc}
X_{11} & \cdots & X_{1 n} \\
\vdots & \ddots & \vdots \\
X_{n 1} & \cdots & X_{n n}
\end{array}\right] .
$$

Sugeneruojame svorių matricą: kur $W$ - kriterijaus svoris

$$
W_{i j}=\frac{\sum_{i=1}^{n} X_{i n}}{n}=\left[\begin{array}{c}
W_{11} \\
\vdots \\
W_{1 n}
\end{array}\right]
$$

Toliau daroma suderinamumo analizè ir apskaičiuojamas suderinamumo matas:

$$
C v_{i j}=\left[\begin{array}{ccc}
C_{11} & \cdots & C_{1 n} \\
\vdots & \ddots & \vdots \\
C_{n 1} & \cdots & C_{n n}
\end{array}\right] \times\left[\begin{array}{c}
W_{11} \\
\vdots \\
W_{1 n}
\end{array}\right]=\left[\begin{array}{c}
C v_{11} \\
\vdots \\
C v_{1 n}
\end{array}\right]
$$

Apskaičiuojame lambda $(\lambda)$ pagal formulę:

$$
\lambda=\frac{C v_{i j}}{W_{i j}} .
$$

Suderinamumo indeksą apskaičiuojame pagal formulę:

$$
C I=\frac{\lambda-n}{n-1} .
$$


Suderinamumo santykio apskaičiavimas: kur $C R$ - suderinamumo koeficientas; $I R$ - atsitiktinis indeksas:

$$
C R=\frac{C I}{R I}
$$

\subsection{SAW metodas}

SAW (angl. Simple Additive Weighting) metodu nustatoma kiekvieno j-tojo objekto (alternatyvos) visų rodikliu svertinių normalizuotų reikšmių suma $S_{j}$.

$$
S_{j}=\sum_{i=1}^{m} w_{i} \bar{r}_{i j}
$$

čia : $w_{i}-i$-tojo rodiklio svoris; $\bar{r}_{i j}-j$-tojo objekto, $i$-tojo rodiklio normalizuotoji reikšmè. Pradiniai duomenys, jeigu kriterijus yra minimizuojantis, normalizuojami pagal formulę:

$$
\bar{r}_{i j}=\frac{\min _{j} r_{i j}}{r_{i j}} .
$$

čia: $\bar{r}_{i j}-j$-tosios alternatyvos $i$-tojo kriterijaus reikšmè.

Jeigu kriterijus yra maksimizuojantis tai normalizuojama pagal formulę:

$$
\bar{r}_{i j}=\frac{r_{i j}}{\max _{j} r_{i j}} .
$$

\subsection{TOPSIS metodas}

TOPSIS (angl. Technique for Order of Preference by Similarity to Ideal Solution) metodu apskaičiuojamas atstumas tarp idealaus neigiamo ir idealaus teigiamo sprendimo, kadangi kriterijams svorius priskyrėme visus vienodus, tai pirmu žingsniu atliekamas matricos normalizavimas pagal formulę:

$$
n_{i j}=\frac{x_{i j}}{\sqrt{\sum_{i=1}^{m} x_{i j}^{2}}} .
$$

Toliau apskaičiuojame svertinę matricą pagal formulę:

$$
v_{i j}=w_{j} n_{i j} \text { for } i=1, \ldots, m ; j=1, \ldots, n,
$$

čia $: w_{j}-j$-ojo kriterijaus svoris.

Kitu žingsniu apskaičiuojama idealus teigiamas ir idealus neigiamas sprendimai pagal formules:

$$
\begin{aligned}
& V^{+}=\left(v_{1}^{+}, v_{2}^{+}, \ldots, v_{n}^{+}\right)=\left(\left(\max _{i} v_{i j} \mid j \in I\right),\left(\min _{i} v_{i j} \mid j \in J\right)\right) \\
& V^{-}=\left(v_{1}^{-}, v_{2}^{-}, \ldots, v_{n}^{-}\right)=\left(\left(\min _{i} v_{i j} \mid j \in I\right),\left(\max _{i} v_{i j} \mid j \in J\right)\right),
\end{aligned}
$$

kur $I$ tapatinamas su maksimizuojančiu, o $J$ su minimizuojančiu kriterijumi, $i=1, \ldots m ; j=1, \ldots, n$.

Toliau apskaičiuojami atstumai tarp idealaus teigiamo ir idealaus neigiamo sprendimo pagal formules:

$$
\begin{aligned}
& S_{i}^{+}=\sqrt{\sum_{j=1}^{n}\left(v_{i j}-v_{i}^{+}\right)^{2}}, i=1,2, \ldots, m ; \\
& S_{i}^{-}=\sqrt{\sum_{j=1}^{n}\left(v_{i j}-v_{i}^{-}\right)^{2}}, i=1,2, \ldots, m .
\end{aligned}
$$


Toliau apskaičiuojamas santykinis artumas idealiam teigiamam sprendimui pagal formulę:

$$
P_{i}=\frac{S_{i}^{-}}{S_{i}^{-}+S_{i}^{+}}
$$

Paskutiniu žingsniu suranguojami tiriami objektai.

Daugiakriterinio vertinimo tikslas - suformuoti vientisą rodiklių sistemą ir ją praktiškai pritaikyti Baltijos šalių oro uostų ekonomikos sektoriaus ekonomikos globalizacijos sąlygomis plètros vertinimui atlikti, tyrimas atliktas dviem metodais siekiant tyrimo objektyvumo.

\section{Baltijos šalių oro uostų ekonomikos sektoriaus plètros vertinimo tyrimas}

Nustatyti ar ekspertų vertinimai yra suderinti apskaičiuotas Kendall konkordacijos koeficientas, kuris gautas $17,28>9,48$ ir nuliné hipotezė buvo atmesta. Taigi galime teigti, kad ekspertų vertinimai yra suderinti. Visi apklausti ekspertai vienbalsiai nusprende, kad svarbiausias rodiklis parodantis oro uosto efektyvumą yra keleivių skaičius oro uoste, kitų rodiklių svarbumas nežymiai skyrèsi.

Siekiant įvertinti Baltijos šalių oro uostų ekonomikos sektoriaus plètrą ekonomikos globalizacijos sąlygomis pasirinkau daugiakriterini vertinimą naudojant SAW ir TOPSIS metodus. Tyrimui atlikti buvo naudojami 2018 metų Rygos, Talino ir Vilniaus tarptautinių oro uostų statistiniai duomenys. Apskaičiavus SAW metodu gauti rezultatai (žr. 5 lentelę):

5 lentelè. Rygos, Talino ir Vilniaus oro uostų rodikliai skaičiuojant SAW metodu (Lentelè sudaryta autorès)

\begin{tabular}{|l|c|c|c|}
\hline & Vilniaus oro uostas & Rygos oro uostas & Talino oro uostas \\
\hline Keleiviai & 0,288 & 0,460 & 0,153 \\
\hline Orlaivių judejjimas & 0,001 & 0,003 & 0,002 \\
\hline Kroviniai tūkst./t. & 0,003 & 0,001 & 0,000 \\
\hline Oro vežėjų skaičius & 0,000 & 0,000 & 0,000 \\
\hline Tiesioginės kryptys & 0,000 & 0,000 & 0,000 \\
\hline Suma & 0,292 & 0,464 & 0,155 \\
\hline
\end{tabular}

Remiantis gautais rezultatais, matome, kad Rygos oro uostas yra pirmoje vietoje, pagal ekonomikos sektoriaus rodiklius. Taigi Rygos oro uosto ekonomine pletra yra efektyviausiai orientuota ekonomikos globalizacijos sąlygomis. Toliau pagal SAW metodą Vilniaus oro uostas ir Talino oro uostas.

Atlikus tyrimą pagal TOPSIS metodą gauti rezultatai (žr. 6 lentelę):

6 lentelè. Rygos, Talino ir Vilniaus oro uostų rodikliai skaičiuojant TOPSIS metodu (Lentelè sudaryta autorės)

\begin{tabular}{|c|c|c|c|}
\hline Oro uostas & Vilniaus oro uostas & Rygos oro uostas & Talino oro uostas \\
\hline $\begin{array}{c}\text { Santykinis artumas idealiam } \\
\text { teigiamam sprendimui }\end{array}$ & 0,2670 & 0,3370 & 0,2370 \\
\hline
\end{tabular}

Atlikus skaičiavimus TOPSIS metodu gauti tokie patys rezultatai, kaip ir SAW metodu vertinant oro uostu ekonomikos sektoriaus plètrą ekonomikos globalizacijos sąlygomis. Taigi Rygos oro uostas yra pirmoje vietoje, Vilniaus antroje, o Talino trečioje.

Rygos oro uostas ženkliai labiau ekonomiškai išsivystęs lyginant su Vilniaus ir Talino, aptarnauja daugiau keleivių, vykdo daugiau skrydžių, didesnis orlaivių parkas ir infrastruktūra labiau orientuota ị globalios ekonomikos diktuojamas sąlygas. Rygos oro uostas ir toliau vysto didelius investicnius projektus skirtus oro uosto plètrai. Šis oro uostas yra pranašesnis už Vilniaus ir Talino, dar ir dèl to, kad turi nuosavas oro linijas Air Baltic, kurios užima didžiają dali rinkos Rygos oro uoste, tai labai svarbus rodiklis visos šalies ekonomikai. Civilinės aviacijos plètra reikalauja ir oro uostų pasirengimo, tačiau Vilniaus ir Talino oro uostuose jaučiamas infrastruktūros trūkumas. Tačiau vertinat Vilniaus oro uostą reikètų atsižvelgti ir ị Kauno ir Palangos oro uostus, nes jie papildo vienas kita, juose veikia skirtingi vežèjai ir aptarnaujamos skirtingos keleivių grupès. Ivertinti bendrą jų ekonominę plètrą dabartinès ekonomikos globalizacijos sąlygomis reikètų atlikti visos šalies oro uostų empirinį tyrimą. Vertinat Vilniaus oro uosto plètrą reikia atsižvelgti ị fizines galimybes, kurios yra ribotos, nes aplink Vilniaus oro uosto teritoriją yra nemažai gyvenamujų namų. Talino tarptautinis oro uostas neturi galimybès fiziškai plèstis ir konkuruoti keleivių ir krovinių srautais, tačiau siekia pirmauti tarp patogiausių ir labiausiai technologiškai išsivysčiusių oro uostų. Tvari ir strategiška plètra užtikrina ekonomikos augimą. Talino oro uostas daug investuoja i žmogiškuosius išteklius. 


\section{Išvados}

Šiuolaikinès ekonomikos globalizacijos sąlygomis itin svarbų vaidmenį vaidina oro uostų veikla. Dauguma tarptautinių Europos Sajungos oro uostų ženkliai prisideda prie tų šalių BVP. Kalbant apie Baltijos šalių didžiausius - Rygos, Vilniaus ir Talino tarptautinius oro uostus jie yra stiprus tų valstybiu ekonominis variklis, prisidedantis prie valstybiu ekonominio augimo. Visuose nagrinètuose oro uostuose pastebimas spartus ekonomikos sektoriaus augimas, didèja keleivių srautai, išauga poreikis infrastruktūros plètrai. Rodiklių duomenimis, atlikus empirini vertinimą, galima teigti, kad Vilniaus ir Talino oro uostai iki šios dienos neišnaudoja savo potencialo aptarnauti dar daugiau keleiviu ir vykdyti daugiau skrydžių, tam reikalingas efektyvus vertinimas ir strateginis planas, tų oro uostų plètrai vykdyti. Minèti oro uostai vykdo investicinius projeketus, kurie orientuoti ị inovatyvią plètrą, to rezultatus bus galima nagrinèti, kai bus igyvendinti projektai. Rygos tarptautinis oro uostas, rodikliu duomenimis ir atliktų tyrimų labiausiai prisitaikantis prie globalizacijos procesų. Visos trys Baltijos šalys turi panašią geografinę padètị, kuri labai palanki tranzitui. Tam labai svarbu plèsti ir neaviacinių paslaugų sektorių viešbučiai šalia oro uosto, automobilių stovejjimo aikštelès, kavinès, taksi ir kita. Paslaugų kainos turètu atitikti tos šalies vartojimo galią. Sektini pavyzdžiai turètų būti didžiausi Europos Sajungos oro uostai - technologiju pažangumas, orlaivių parkų plètra, darbuotojų motyvavimas, saugumas, infrastruktūros išvystymas, tinklų kūrimas. Pagrindinès visų trijų oro uostų kryptys yra susijusios su šių šalių emigracijos problema. Daugiausiai skrydžiu vykdoma ir daugiausiai keleivių vyksta ị pagrindines emigracijos šalis, didžiausi rodikliai - Londono oro uostai. Iki šios dienos labai svarbus Jungtinès Karalystės pasitraukimo iš ES klausimas, kuris vienareikšmiškai paveiks visu trijų oro uostų srautus ị šią šalį. Galime daryti prielaidą, kad Brexit neigiamai paveiks oro uostų ekonomiką, ir oro uostai jau šiandien turètų būti parengę strateginius planus ar bent numatomų veiksmų planą po Brexit. Sparčiai greitejjant ekonominès globalizacijos ciklų kaitai, reikalingas prisitaikymas, kuris užtikrintų efektyvų konkurencingumą visos aviacijos srityje. Laisvèjančios rinkos epochoje privalomas inovacijų diegimas, dar kitaip apibūdinamas kaip sinerginio efekto apraiška. Globalizacijos sąlygomis, kuriant ekonomines inovacijas oro uostų plètros strategijose apjungiama daugybę skirtingo pobūdžio dalykų ir resursų, atsiranda stipraus ir efektyvaus kontroliavimo poreikis.

Atlikus Baltijos šalių oro uostų ekonomikos sektoriaus plètros tyrimą ekonomikos globalizacijos sąlygomis, galima teigti, kad rinkoje esame per maži konkuruoti po vieną, oro uostai nepajegūs parduoti tiek kiek jų prašoma. Atskiri Baltijos šaliu oro uostai šiai dienai neatitinka standartu, kuriu reikalauja rinka. Glaudesnis bendradarbiavimas ir tinklo kūrimas turètų būti Baltijos šalių oro uostų tikslas, norint užimti didesnę rinkos dalị ir tapti pajègiais konkuruoti Europos Sajungos mastu. Būtinas pačių oro uostų potencialo tyrimas ir jo išnaudojimas.

Taigi, oro uostu veikla yra neatsiejama nuo bendros ekonomikos globalizacijos visame pasaulyje ir valstybès yra stipriai ekonomiškai veikiamos oro uostų ekonominès plètros. Valstybės turètų stipriai prisidèti prie oro uostụ ekonominès plètros ir pažangumo skatinimo. Reikia kompleksiškai vertinti oro uostų ekonominị augimą, kaip visos infrastruktūros plètrą kuri ịtakoja oro uosto efektyvumo galimybes. Oro uostas nèra pats savaime veikiantis subjektas, tai ekonomikos globalizacijos ir ekonomikos augimo varomoji jega, kurią reikia vertinti atsižvelgiant i daug kriterijų, tokių kaip - inovacijos, technologinè pažanga apimanti visą sektorių, žmogiškieji ištekliai, statistiniai duomenys, infrastruktūros pletra - susisiekimas su oro uostu, išvykimas iš oro uosto, apgyvendinimas šalia oro uosto, viešasis transportas iš ir ị oro uotą, taksi paslaugos ir kt.

Naudojantis šiais vertinimo metodais sukuriama kompleksinio vertinimo sistema, kuria galima objektyviau įvertinti atskirų Baltijos šalių oro uostų, ekonomikos sektoriaus, plètros potencialą ir taip pat jų bendradarbiavimo galimybes ekonomikos globalizacijos sąlygomis ir vertinimą kaip vieno subjekto galimybes pasaulineje rinkoje, o ne atskiro vieneto. Ekonomikos globalizacijos sąlygomis svarbu ịvertinti Baltijos šalių oro uostų integravimąsi i Europos Sajungos ir pasaulio aviacijos tinklus, kurie skatintų inovaciniu procesų igyvendinimą, pavyzdžiui tokiu kaip žiedinès ekonomikos ịgyvendinimą, apie kurią Baltijos šalių aviacijos sektorius kalba dar labai mažai, o ir igyvendinimo galimybės, jeigu veiktų kaip atskiri subjektai būtų ribotos, tačiau sukuriant Baltijos šalių oro uostų bendradarbiavimo tinklą, galimas efektyvus žiedinès ekonomikos iggvendinimas pasidalijant funkcijas.

\section{Literatūra}

Airport Aviation Association. (2016). Connecting the UK'S economy. How better access to airports can boost growth. https://www.aoa.org.uk/wp-content/uploads/2016/11/AOA-Connecting-the-UK-Economy.pdf

Baltazar, M. E., Rosa, T., \& Silva, J. (2018). Global decision support for airport performance and efficiency assessment. Journal of Air Transport Management, 71, 220-242. https://doi.org/10.1016/j.jairtraman.2018.04.009

Chaouk, M., Pagliari, D. R., \& Moxon, R. (2020). The impact of national macro-environment exogenous variables on airport efficiency. Journal of Air Transport Management, 82. https://doi.org/10.1016/j.jairtraman.2019.101740

IATA. (2017). Aviation benefits 2017 civil air navigation services organisation. Monreal.

ICAO. (2018). Economic development of air transport. https://www.icao.int/annual-report-2018/Pages/progress-on-icaosstrategic-objectives-economic-development-policy-regulation.aspx

Lietuvos oro uostai. (2019). 2018 m. veiklos ataskaita. Vilnius.

RIX. (2015). Riga airport business plan and action. Ryga. 
RIX. (2019). Passengers-incoming +outgoing passengers, including direct transit passengers. Ryga.

Sentance, A. (2015). Connectivity and growth - Issues and challenges for airport investment. https://www.readkong.com/page/connectivity-and-growth-issues-and-challenges-for-airport-5846430?p=1

Tallat-Kelpšaite, Z. (2019). IATA: aviation has significant footprint in Latvian economy. http://www.jura.lt/en/news/1618iata-aviation-has-significant-footprint-in-latvian-economy

Tallinn Airport. (2019). Anual report. Tallinn.

Vahtla, A. (2019). Hoping to grow, Tallinn Airport plans passenger terminal expansion. News $\mid$ ERR. https://news.err.ee/903879/hoping-to-grow-tallinn-airport-plans-passenger-terminal-expansion

VIt Lietuvos oro uostai. (2019). Vị Lietuvos oro uostai Vilniaus filialas traffic report 2018. Vilnius.

\title{
EVALUATION OF THE BALTIC AIRPORT ECONOMIC DEVELOPMENT UNDER THE CONDITIONS OF ECONOMIC GLOBALIZATION
}

\section{Eglè SIKORSKAITÉ-NARKUN, Kęstutis PELECKIS}

\begin{abstract}
Changes in airport economic development and globalization are becoming central to the overall economic and infrastructure development of the country and its assessment. Airport brands contribute to countries' GDP. This paper analyzes the level of globalization of the Baltic economy. There are three major international airports in the Baltic States - Riga, Vilnius and Tallinn. In the context of globalization, the problem of the airport economic sector is adapting to rapid changes and changing conditions. External factors affecting the development of the airport economic sector are described. New authors "and institutions" approaches to economic development and globalization are explored. Implications for airport development processes are analyzed. The impact of globalization on the development of the airport economic sector is discussed.
\end{abstract}

Keywords: global economy, airport economic sector development, globalization, Baltic airports, economic development, innovation, technology development, infrastructure development. 